\title{
Influences of Product Attribute and Event Marketing Toward Customers' Behavior in Buying a Car Toyota New Yaris
}

\author{
Andri Astuti Itasari*; Andre Rahmanto; Yulius Slamet \\ Faculty of Social and Political Science, Universitas Sebelas Maret, Indonesia \\ Email: Andriastutiitasari@gmail.com
}

http://dx.doi.org/10.18415/ijmmu.v5i5.418

\begin{abstract}
Automotive industry grows up very fast at this time, which has big key in economic field, even in Indonesia. The purpose of this research $\mathrm{s}$ to know probability product attribute and event marketing which influence the customers in buying a car named Toyota New Yaris. Data are collected by observation and interviewing the customers who buy Toyota New Yaris and do not. This research use survey method. Analyze technique use regress logistic binary. The result of research shows that product attribute and event marketing influence significant toward customers' behavior to buy Toyota New Yaris in simultaneously. Meanwhile, as individually test, it shows that product attribute significantly and probability value in $0,0008(p<0,005)$, while event marketing is not give influence significantly to customers' behavior to buy Toyota New Yaris with probability value 0,124 $(p>0,05)$.
\end{abstract}

Keywords: Product Attribute; Event Marketing; Customers' Behavior; Toyota New Yaris; Regress Logistic Binary

\section{Introduction}

Automotive industry grow up very fast, it holds important role in economically in each country. Transportation system like car has been growing up well and it holds important role in economics field, even in Indonesia. The automotive industry is trusted for the future will continue to grow due to the broad market conditions and regulatory adjustments that provide positive stimulus. This shows the performance of the automotive industry in Indonesia is quite good and continues to grow. The growing automotive industry proves that people's economic activity is increasing (kemenperin.go.id., 2017).

Toyota is one of automotive industry in Indonesia which growing up well. Toyota New Yaris is one of Toyota brand including hat back, which offer the superior product to customers. Product attribute of Toyota New Yaris is designed modern, elegant, and complete facilities, so it can easy to attract customers. Tjiptono (2008) said that product attribute is an important element viewed by customers in buying a product, and it becomes the basic rule before buy a product. By attribute in a product, customer can judge and measure the suitable of product characteristic with need and willingness. 
Promotion of a product by event marketing is a promotion strategy doing by PT Nasmoco Bengawan Motor Surakarta. Event marketing includes showroom event, public display, customer focus, exhibition, and etc. Hoyle (2002) said that event marketing is a marketing strategy going to innovative ways and creative to attract participants and awareness of public for interaction with company directly. While, Belch and Belch (2012) explains that event marketing is a kind of promotion, which the company or brand makes an event to create an experience for customers and promote the product or services. But, only a superiority product can attract the customers yet in Surakarta. Then, Toyota New Yaris find the decreasing in marketing. The data show, there are 273 unit cars in 2015, there are 273 unit cars in 2016, and there are 147 unit cars in 2017 (Source: Nasmoco Slamet Riyadi).

Although Toyota is a leader market, there are some superior products which are decreasing in marketing. This case indicates that whether the superiority of product attribute offered is not special or whether the role of promotion by event marketing, doing in continue and consistent, does not work well yet. Therefore, that problem attracts to be analyzed ad researched about the influence of attribute product and event marketing toward customers' behavior in buying Toyota New Yaris. The analyze uses regress logistic binary, it can be used to know the influence of product attribute and event marketing towards customers' behavior in buying Toyota New Yaris. Analyze technique of this research is as novelty or research modern.

\section{Literature Review}

A company designs a marketing to defend a long live its company. This design is to increase selling the product. Marketing is a way to develop a product and a good promotion to make interaction with customers. A basic concept in modern marketing or new marketing is marketing strategy consists of product, price, promotion, and distribution which is as a main concept in modern marketing. Kotler and Amstrong (2008:62) said that modern marketing is a blend of collected marketing tools used a company to get customers' respond, so it influences the product demand.

\section{Product Attribute}

Stanton (2007: 119) explains that product is a collected attribute which real and unreal, it includes colors, packs, reseller prestige and service from factory and reseller, which is possible accepted a customer as a product that make satisfy. Zeithaml (2009:50) said that product attribute is a guidance and measure by customers in buying a product. Statement by Zeithaml is supported by Mowen and Minor (1998) in Sedzro et all (2014) suggest a product made from characteristics and part known as attribute used by customers in decision to buy a product.

According to Kotler and Amstrong (2008) explain that product attribute is a part or characteristics of a product which improved to get advantages offered to customers. Then, product attribute explained by Kotler and Amstrong (2008) includes dimension of product quality, product features, style, and product design. Product quality is a main positioning tool in marketing, quality has effect to customers directly in product and service, so quality is related to value and customers' satisfy. Product feature is a tool competitive used to make differences a company product with other competitors. While, style is only describe a product appearance, so style can be attractive or boring. Sensational style can attract customers' attention and get good esthetic, but it is not really make a product be better. Then, design is a concept bigger than a style. Design is a core of product, thus a good design is $n$ only in appearance but also in advantages. 


\section{Event Marketing}

Belch \& Belch, 2003: 543 in Putri et all (2016) said that event marketing is a way to promote (promotional mix), organization creates an activity to give new experience for customers to be remembered and they will buy its product. Zarantonello et all (2013) explains that event marketing is a persuade process and positive ability to influence a brand. This case shows that event marketing has ability to make customers' positive emotional. Increasing respond by customers can create new think from customers, thus their attention be higher too and a message from a brand can be felt.

Meanwhile, Hoyle (2002) explains there are three basic of evaluation of event marketing, namely; entertainment, excitement, and enterprise. Entertainment means an event designed to entertain customers so they feel a new different thing in event. Excitement is a key to be success in an event for customers. Excitement can be got by entertainment, so they are linked for each other. Thus, event marketing is packed very well in order to get the maximum result.

Bahrer Larsson (1998) in Eckerstein (2002) explains event marketing is an attempt to coordinate communications in a self-created or sponsored event, which the event is an activity that aggregates the target audience in space and time, so messages can be communicated in an event. Belch \& Belch (2001: 338) in Simboh (2016) said that event marketing is a promotion of a brand using tools as finance aid or support from organization, individual or event which is like sport, entertainment, culture, social supporting high attractiveness by giving feedback in promotion a company. Kennedy (2009) said that event marketing is a part of special promotion to persuade customers directly with giving an additional value in a product in event. It has purpose to sell the product directly to customers from distributors or company.

\section{Customers' Behavior}

American Marketing Association defines customers' behavior as interaction dynamic between influence and awareness, behavior and environment which human do another exchange in living aspects, so customers' behavior involves think and feel, also doing action in consumption process (Peter, Olson., 2013). While, Schiffmann, Kanuk, (2007) explain customers' behavior is centered of an individual who take a decision for usage their resource (time, money, work) to buy things, so it is liked with what they buy, why they buy, when they buy, where they buy, how often they buy and how often they use it. Therefore, a company must know what become the needs and willingness of customers, so company can fill the customers' taste which means the satisfaction of customers.

\section{Methodology}

This research uses quantitative method. Research design in collecting data uses explanative method. Research method uses survey research. Population and sample is respondents who buy Toyota New Yaris in Nasmoco branch Slamet Riyadi Surakarta and respondents who do not buy but they can buy a car, so it can be linier with respondent who buy Toyota New Yaris. A method to take sample is theorem limit central. A method to take sample nonprobability is by using quota sampling. Quota sampling means a researcher determines quota in each stratum in relevancy and proportional to representative its population (Slamet., 2006). This research uses ordinal measure scale called Likert scale. Analyze technique uses regress logistics binary. 


\section{Results}

The result of this research shows as together (Omnibus test of model coefficients) give the test all of variables coefficient in regress logistics. Score of chi-square is 8,205 with $2 \mathrm{df}$ and significant $(p=$ 0,017), so it can be concluded that product attribute and event marketing give significant influence for customers to buy a car. Then, it can be guidance for taking decision to refuse Ho and accept Ha, so it forwards to individual test. The result of research is shown in Table 1 below:

Table 1 Omnibus tests of model coefficients

\begin{tabular}{lllll}
\hline & & Chi-square & Df & Sig. \\
\hline Step 1 & Step & 8,205 & 2 &, 017 \\
& Block & 8,205 & 2 &, 017 \\
& Model & 8,205 & 2 &, 017 \\
\hline
\end{tabular}

Source: primer data proceed, 2018

Meanwhile Table 2 shows goodness of fit test logit model, score of nagelkerke $\mathrm{R}$ square is 0,017 , it means product attribute variable $\left(\mathrm{X}_{1}\right)$ and event marketing $\left(\mathrm{X}_{2}\right)$ in logit model shows customers in buying a car or not about $1,7 \%$.

Table 2 Goodness test of fit model summary

\begin{tabular}{lllll} 
& & & Cox & $\&$ \\
& $-2 \quad$ Log & Snell & R & Nagelkerke \\
Step & likelihood & Square & & R Square \\
\hline 1 & $74,973(a)$ &, 128 &, 170 \\
\hline \multicolumn{4}{l}{ Source: } & primer data proceed, 2018
\end{tabular}

Table 3 Variables in the equation

\begin{tabular}{|c|c|c|c|c|c|c|c|c|c|}
\hline & \multirow{2}{*}{$\begin{array}{l}\text { B } \\
\text { Lower }\end{array}$} & \multirow{2}{*}{$\begin{array}{l}\text { S.E. } \\
\text { Upper }\end{array}$} & \multirow{2}{*}{$\begin{array}{l}\text { Wald } \\
\text { Lower }\end{array}$} & \multirow{2}{*}{$\begin{array}{l}\text { Df } \\
\text { Upper }\end{array}$} & \multirow{2}{*}{$\begin{array}{l}\text { Sig. } \\
\text { Lower }\end{array}$} & \multirow{2}{*}{$\begin{array}{l}\operatorname{Exp}(B) \\
\text { Upper }\end{array}$} & \multicolumn{2}{|c|}{ 95,0\% C.I.for $\mathrm{EXP}(\mathrm{B})$} \\
\hline & & & & & & & & Lower & Upper \\
\hline Step & AP &, 244 & ,093 & 6,967 & 1 & ,008 & 1,277 & 1,065 & 1,531 \\
\hline 1(a) & $\begin{array}{l}\text { EM } \\
\text { Constant }\end{array}$ & $\begin{array}{l}-, 077 \\
-5.720\end{array}$ & $\begin{array}{l}, 050 \\
2.523\end{array}$ & $\begin{array}{l}2,363 \\
5,141\end{array}$ & $\begin{array}{l}1 \\
1\end{array}$ & $\begin{array}{r}124 \\
023\end{array}$ & $\begin{array}{r}926 \\
003\end{array}$ & 840 & 1,021 \\
\hline
\end{tabular}

Source: primer data proceed, 2018

Based on logistics regress result in Table 3 can be made logistics regress model as follow:

$\ln \left(\frac{P_{i}}{1-P_{i}}\right)=-5,720+0,244-0,077$ 


\section{Interpretation:}

a. Constanta $-5,720$ with negative parameter shows if there is no product attribute $\left(\mathrm{X}_{1}\right)$ and event marketing $\left(\mathrm{X}_{2}\right)$, so customers behavior in buying a car will decrease -5,720. Coefficient regress product attribute $\left(\mathrm{X}_{1}\right)$ as 0,244 with positive parameter, which means if there is increasing variable of product attribute as one unit will cause the increasing customers behavior in buying a car as 0,244 with assumption of event marketing variable $\left(\mathrm{X}_{2}\right)$ supposed constant. Coefficient regress of event marketing $\left(\mathrm{X}_{2}\right)$ as $-0,077$ with negative parameter means if there increasing variable in event marketing as one unit will cause decreasing toward customers behavior in buying a car as $-0,077$ with assumption variable of product attribute $\left(\mathrm{X}_{1}\right)$.

b. Score antilog of coefficient B in Exp (B) column is as odds ratio that odds ratio for product attribute $\left(\mathrm{X}_{1}\right)$ as 1,277 , means if product attribute high so possibly customers behavior in buying a car is higher than do not do as 1,277 times. While, Odds ratio for event marketing $\left(\mathrm{X}_{2}\right)$ as 0,926 , means if event marketing is going better so possibly ratio of customers' behavior in buying a car is higher than do not do as 0,926 times.

c. The result of significant of independent variable individually using statistic test Wald that is variable of product attribute $\left(\mathrm{X}_{1}\right)$ has Wald score as 6,967 and probability as $0,008(p<0,05)$, so that $\mathrm{H}_{0}$ rejected and $\mathrm{H}_{\mathrm{a}}$ accepted. This result shows that there is an influence of product attribute for customers to buy a car Toyota New Yaris. While, variable of event marketing $\left(\mathrm{X}_{2}\right)$ has Wald score 2,363 and probability as $0,124(p>0,05)$, so that $\mathrm{H}_{0}$ accepted and $\mathrm{H}_{\mathrm{a}}$ rejected. This result shows that there is no influence of event marketing for customers to buy a car Toyota New Yaris.

\section{Discussion}

This research explains that product attribute can give significant influence toward customers' behavior in buying a car. Tjiptono (2008: 103) explains that product attribute is an important part of customers for guiding to buy a car. Product attribute is used by customers to give score and measure the characteristics of benefit product to fill the needs and willingness. Product attribute is very important for customers. It becomes a basic for buying because customers will do reaction with product and its attribute inside. Product attribute is a component, which has product characteristics, and guarantees its product for satisfaction the customers. It proves that product attribute becomes important for customers to choose and buy a product. Toyota designs an unique characteristic to appears the attribute, so customers can give value and measure about the characteristic of product and also can find the differences with others, and will buy in ending. This opinion is in line with research by Subagio dkk (2015) entitled the influence product attribute toward customers' decision (study on customers in a product named Low Cost Green Car Astra Daihatsu Ayla in PT. Jolo Abadi, Malang). The result of Risad research is variable of product attribute as togetherness can significant influence toward buying decision.

Meanwhile, variable of event marketing does not have significant influence toward decision in buying because data by respondent has many variety from customers who buying a product and do not do. This research is in line with research of Ningrum, Nilowardono (2016). The result of the research shows that event and brand image give significant influence as simultaneous toward decision to buy a product, but when partial test show that event do not give significant influence toward interested in buying a product. Car purchases are categorized as high involvement due to many considerations in buying decision process. High-involvement purchases are important purchases for consumers due to their perceived high risk factors and extensive problem-solving and information processing. Event marketing is expected to provide an opportunity for consumers to interact directly with the company, so the event requires the involvement of visitors. This is in line with Solomon (2011) stating that the existence of 
event involvement, visitors are expect to have views that are influenced by the needs, values, interests or experience during the interaction directly or indirectly with these activities. By applying the right promotional event strategy and special product attributes expected the product can be accepted by the target, so that consumers tend to buy Toyota New Yaris.

\section{Conclusion}

Products attribute and event marketing has significant influence as simultaneous toward customers' behavior in buying Toyota New Yaris. But, for significant test individually shows that product attribute give significant influence toward customers' behavior in buying a car, but event marketing does not. Score of probability of product attribute is as 0,008 and event marketing as 0,124.

\section{References}

Belch, George E and Belch, Michael E. (2012). Advertising and Promotion: An Integrated Marketing Communication Perspective Global Edition. New York: McGraw Hill.

Eckerstein. (2002). Evaluation of Event Marketing. Goteborg University. International Management. Master Thesis No 2002: 25.

Hoyle, Leonard H. (2002). How to Successfully Promote Events, Festival, Convention \& Expositions, New York John Willey \& Sons, Inc.

Kennedy, John E. (2009). Manajemen Even: Promosi Penjualan, Pameran, Seminar, Pertemuan bisnis dan Konferensi Pers. Buana Ilmu Populer, Jakarta.

Kotler, Philip \& Armstrong, Gary. (2008). Prinsip Prinsip Pemasaran Jilid I Edisi Kedua Belas. Jakarta: Penerbit Erlangga.

Menperin Apresiasi Perkembangan Industri Otomotif Indonesia. (2017). Diakses dari http://www.kemenperin.go.id/artikel/17959/Menperin-Apresiasi-Perkembangan-Industri-OtomotifIndonesia. Diakses pada 10 Agustus 2017.

Ningrum, Nilowardono. (2016). Pengaruh Event dan Brand Image Terhadap Minat Beli Produk Rokok Sampoerna A. Mild Pada PT. HM Sampoerna Area Marketing Surabaya. Jurnal Manajemen Kinerja, 2(1). ISSN: 2407-7305.

Olson. (2013). Perilaku konsumen dan Strategi Pemasaran. Edisi 9, buku I. Terjemahan Diah Tantri Dwiandani. Penerbit Salemba Empat.

Putri dkk. (2016). Efektifitas Atmospher Dan Event Marketing Terhadap Keputusan Pembelian yang Dimediasi Oleh Minat Beli Pada Konsumen Tembi Rumah Budaya Yogyakarta. Journal of Management, 2(2).

Schiffman, Leon G, Lesiie Lazar Kanuk. (2007). Consumer Behavior. Pearson Education International.

Sedzro et all. (2014). Determinants of Automobile Purchase and Brand Choice in Ghana: Multinomial Logit Approach. Journal of Transnational Management, 19(4): 303-317. ISSN:1547-5778, DOI:10.1080/15475778.2014.948791. 
Simboh. S.M. (2016). Penerapan Strategi Event Marketing sebagai Gaya Peningkatan Volume Traffic Pengunjung The Park Mall. Laporan Tugas Akhir.

Slamet, Y. (2006). Metode Penelitian Sosial. Sebelas Maret University Press.

Solomon M.R (2011). Consumer Behaviour: Buying, Having and Being. Pennsylvania State University: Prentice Hall.

Stanton.William J. (2007). Prinsip Pemasaran Jilid 1 dan 2.. Jakarta, Erlangga.

Subagio dkk. (2015). Pengaruh Atribut Produk Terhadap Keputusan Pembelian (Study pada Konsumen Low Cost Green Car Astra Daihatsu Ayla di PT. Jolo Abadi Malang) Jurnal Administrasi Bisnis, 23(1).

Tjiptono, Fandy. (2008). Strategi Pemasaran. Yogyakarta: Penerbit Andi.

Zarantonello et al. (2013). The Impact of Event Marketing on Brand Equity the Mediating Roles of Brand Experience and Brand Attitude..International Journal of Advertising, 32(2): 255-280.

Zeithaml. VA. (2009). Consumer Perceptions of Price. Quality and Value: A Means End Model and Synthesis of Evidence. Journal of Marketing, 52(Juli 2009): 2-22.

\section{Copyrights}

Copyright for this article is retained by the author(s), with first publication rights granted to the journal.

This is an open-access article distributed under the terms and conditions of the Creative Commons Attribution license (http://creativecommons.org/licenses/by/4.0/). 